\title{
Stress Management in Organizations
}

\author{
Roxana Capotescu ${ }^{1}$ \\ Babeş-Bolyai University, Cluj-Napoca
}

\begin{abstract}
Employee stress has increasingly become a concern for many organizations. Although it is not possible to eliminate stress entirely, people can learn to manage it. Many organizations have adopted occupational stress management programs to try and reduce the stress levels of their workforce. The high cost of work stress related problems highlights the need to spend more time evaluating work stress interventions and publishing the findings so that other organizations can gain insight into programs of merit. This article explore the three major approaches in stress management - primary, secondary and tertiary prevention and outline the importance of an evidence-based approach to stress management interventions. It is argued that an evidencebased approach will lead to advances in intervention practices. We also outline recommendations regarding planning and interpreting occupational stress management research in order to improve stress management interventions.
\end{abstract}

Key words: occupational stress, primary prevention, secondary prevention, tertiary prevention, evidence-based interventions.

\begin{abstract}
Rezumat
În prezent stresul ocupațional a devenit o preocupare pentru tot mai multe organizații. Deşi stresul nu poate fi eliminat în totalitate, oamenii pot învăța să îl gestioneze. Numeroase organizații au adoptat programe vizând managementul stresului ocupațional, în încercarea de a reduce nivelul de stres al angajaților. Costurile crescute generate de problemele relaționate cu stresul ocupațional evidențiază nevoia de a acorda o atenție crescută evaluării intervențiilor de management al stresului în organizații şi publicării rezultatelor pentru a oferi o imagine asupra meritului acestor programe. Acest articol explorează cele trei abordări majore în managementul stresului - prevenția primară, secundară şi terțiară şi susține importanța unei abordări fundamentate empiric în domeniul managementului stresului. Sunt aduse argumente în sprijinul ideii că o abordare fundamentată empiric va conduce la îmbunătățirea practicii în domeniu. Sunt oferite de asemenea recomandări utile în planificarea şi interpretarea cercetărilor din domeniul managementului stresului, în vederea îmbunătățirii intervențiilor de management al stresului.
\end{abstract}

Cuvinte cheie: stres ocupațional, prevenție primară, prevenție secundară, prevenție terțiară, intervenții fundamentate empiric

\section{Introduction}

Organizations provide a major portion of the total stress experienced by a person as a result of the amount of time spent on the job, the demands for performance, and the interaction with others in the workplace.

Stress at work is claimed to have increased in most of the developed and developing world. The drive toward manpower

\footnotetext{
${ }^{1}$ Adresa de corespondență: capotescu_roxana@yahoo.com
}

cost-cutting has led to fewer people doing more work and feeling more insecure in their jobs. The rapid expansion of information technology through the Internet has meant the added burden of information overload, the accelerating pace of work, and demands for immediacy of response in 7 day-24 hour work cultures (Kenny \& Cooper, 2003). Hours of work have also increased in many countries, which has had adverse effects on the work-life balance of the employees.

Stress and health have become important topics in modern society. According 
to research cited by the National Institute for Occupational Safety and Health (NIOSH), 40\% of employees believe their jobs are "very" or "extremely" stressful and at least $26 \%$ of employees feel "burned out" at work (Grawitch, Trares, \& Kohler, 2007). The American Psychological Association (APA) reports that job stress costs U.S. companies about $\$ 300$ billion a year in absenteeism, productivity loss, turnover, and health care costs (Grawitch, Trares, \& Kohler, 2007). In light of such statistics, it is not surprising that companies have begun to focus more and more on developing workplace preventive programs that target the physical and mental health of their employees.

Although stress is somewhat stigmatized, people find it easier to talk about stress than "psychological issues" or "mental health". Employers and employees generally view stress as related in some way both to work and to non-work life. The question What stress do you experience? is meaningful and relevant for adults in every demographic and occupational category. Given an appropriate setting, many if not most adults are interested in considering whether their stress situation could be improved (Martin, 1992).

\section{Stress prevention in organizational context}

Although it is not possible to eliminate stress entirely, people can learn to manage it. Many organizations have adopted stress management training programs to try and reduce the stress levels of their workforce.

Preventive stress management helps one convert stress from a threat into an opportunity for health and achievement. The knowledge and understanding of the physiological and psychological elements of stress have been advanced dramatically over the past 40 years. The field of stress is still an active and fertile one, and the concerns centered on preventive stress management in organizations are also active (Quick, Quick, Nelson, \& Hurrell,1997). Therefore, the questions for those in the field are as follows: Where do we go from here? How do we turn a potential threat into an opportunity? We believe there is an active agenda for at least seven constituencies concerned with stress in organizations. These constituencies include: scientists and researchers, executives and leaders, educators and trainers, physicians, psychologists, employees, and public health officials.

Prevention is always the best public health strategy for any disease epidemic. Quick, Quick, Nelson, and Hurrell (1997) have translated and applied the public health notions of prevention to organizational stress, framing the theory of preventive stress management. If job stress has become an epidemic in America and other industrialized nations, then prevention holds the best hope for addressing this epidemic. Using the public health and preventive medicine model, Quick and colleagues (1997) classified prevention strategies into primary, secondary, and tertiary. Primary prevention aims to modify and manage the demands of the work environment. Secondary prevention aims to modify and manage the individual's response to these demands. Tertiary prevention aims to help and provide aid to those in frank distress.

Scientific inquiry into stress has been inhibited by the lack of a clear, generally accepted definition of what we mean by stress. Fortunately, there is at least modest agreement that stress involves a combination of one or more of the following: an environmental stimulus, or stressor, often described as a force applied to the individual; an individual's psychological or physical response to such forces; or, the interaction between these two (Jex, Beehr \& Roberts, \& 1992; Schonfeld, Rhee, \& Xia, 1995; Le Blanc, Jonge, \& Schaufeli, 2000). The existing research on stress has focused on the physiological, psychological, or behavioral outcomes resulting from exposure to stressors that are appraised as aversive or unpleasant (Capotescu, 2006). Much of this research is, in turn, devoted to the ways in which individuals cope with these stressful experiences (Lazarus, DeLongis, Folkman, \& Gruen, 1985). In addition, there has been an interest in preventive actions designed either to reduce the presence of stressors or neutralize their stress-producing potential (Ivancevich, Matteson, Freedman, \& Philips, 1990).

Our understanding of occupational stress has been shaped and changed by the powerful political, cultural, social, and economic forces in which work occurs and in which people respond to their work experiences. Our way of constructing occupational stress has a direct influence on how it is managed. The two competing constructions of occupational stress as either a "personal trouble" related to personality 
characteristics or a "public concern" related primarily to work characteristics and the epidemiology of occupational health underpin very different stress management interventions in occupational settings (Kenny \& Cooper, 2003).

These observations provide a strong mandate for conducting research into the factors that precipitate occupational stress and to identify effective interventions that can be implemented to treat, manage, and, we hope, prevent the occurrence of this phenomenon.

\section{Types of occupational stress management interventions}

Occupational stress management interventions have been defined as "any activity, program, or opportunity initiated by an organization, which focuses on reducing the presence of work-related stressors or on assisting individuals to minimize the negative outcomes of exposure to these stressors" (Briner, 1997).

The general aims of occupational stress management interventions are: to reduce the presence of work-related stressors, to assist individuals to minimize the negative outcomes of exposure to these stressors, and, from an organization's point of view, to improve the levels of those phenomena which are assumed to be caused by stress, including absence, turnover and lowered performance and motivation. Before discussing in detail some of the ways in which stress management interventions can be made more valid, the characteristics of the three types of management interventions will be considered.

Interventions in occupational stress management are typically classified into primary, secondary, or tertiary approaches. Primary approaches include strategies that aim to prevent the occurrence of work stress, secondary approaches are activities designed to change an individual's reaction to stressors (e.g., by means of relaxation training and team building), and tertiary approaches are those that are used to treat the symptoms of stress and strain after they have been identified (Caulfield, Chang, Dollard, and Elshaug, 2004). Preventive intervention is, in fact, an integrated set of three levels of action.

Primary prevention is concerned with taking action to modify or eliminate sources of stress inherent in the work environment and thus reduce their negative impact on the individual. The "interactionist" approach to stress depicts stress as the consequences of the "lack of fit" between the needs and demands of the individual and his/her environment (French, Caplan, \& Harrison, 1982, in Le Blanc, de Jonge \& Schaufeli, 2000). The focus of primary interventions is in adapting the environment to "fit" the individual.

Elkin and Rosch (in Cooper \& Cartwright, 2001) summarize a useful range of possible strategies to reduce workplace stressors:

- Redesign the task.

- Redesign the work environment.

- Establish flexible work schedules.

- Encourage participative management.

- Include the employee in career development.

- Analyze work roles and establish goals.

- Provide social support and feedback.

- Build cohesive teams.

- Establish fair employment policies.

- Share the rewards.

It must be noted that primary prevention efforts at work, in the form of job or task redesign or modifications of organizational structure or function, can themselves create stress in workers. This can occur for two reasons: (a) change of any kind, even positive change, produces new demands that require adaptation on the part of the worker and (b) changes made at one level in the organization often have unintended and negative consequences at other levels (Quick, Murphy, Hurrell, \& Orman, 1992).

Primary prevention is the preferred point of action. Elimination or amelioration of the occupational mental health risk minimizes the need for using either secondary or tertiary prevention, although both must be available.

In organizational settings, secondary prevention plays a role in easing the adjunctive stress effects of primary prevention efforts. There are individuals who will exhibit some early warning signs of distress as well as unique stress responses regardless of how aggressively primary prevention is pursued.

Secondary prevention is essentially concerned with the prompt detection and management of experienced stress by increasing awareness and improving the stress management skills of the individual through training and educational activities (Cooper \& Cartwright, 1997). It is particularly useful in helping individuals deal with stressors inherent in the work environment that cannot be changed and have to be "lived with" like, for 
example, job insecurity or non-work related aspects of life.

Individual factors can alter or modify the way employees exposed to workplace stressors perceive and react to this environment. Some key factors or "moderator" variables that influence an individual's vulnerability to stress include their personality (Bruck \& Allen, 2003; Contrada, 1989; Daniels \& Guppy, 1997) , their coping strategies (Krajewski \& Goffin, 2006), age (Gross, Carstensen, Tsai, Skorpen \& Hsu, 1997), gender (Long, Kahn \& Schultz, 1992 ; Long \& Schultz, 1995 ; Shaffer, Bell, Joplin, Lau \& Oguz, 2000; Portello \& Long, 2001 ; Eddleston, Veiga \& Powell, 2006), attitudes (Atella, 1999; Best, Stapleton \& Downey, 2005; Cassidy \& O'Connor, 2004; Peake \& Harris, 2002) and the degree of social support available from family, friends, and work colleagues (Aryee, Luk, Leung, \& Lo, 1999; Hochwarter, Witt, Treadway \& Ferris, 2006; Hudek-Knezevic \& Kardum, 2000).

Secondary prevention can focus on developing self-awareness and providing individuals with a number of basic relaxation techniques. Health promotion activities and lifestyle modification programs also fall into the category of secondary level interventions.

Stress education and stress management training serve a useful function in helping individuals to recognize the symptoms of stress, and to overcome much of the negativity and stigma still associated with the stress label. Awareness activities and skills training programs designed to improve relaxation techniques, cognitive coping skills, and work/lifestyle modification skills (e.g., time management courses or assertiveness training) have an important part to play in extending the individual's physical and psychological resources (Cooper \& Cartwright, 1997).

Tertiary prevention is concerned with the treatment, rehabilitation, and recovery process of those individuals who have suffered or are suffering from serious health related problems as a result of stress. Even in circumstances in which the adverse effects of occupational mental health risks are minimized and individuals' awareness levels as well as strengths are enhanced, unanticipated crises occur or peculiar individual vulnerabilities are exploited by environmental events. Hence, mental health practitioners and stress experts must be prepared to heal those in distress through a range of treatment and therapeutic interventions. The implementation of comprehensive systems and procedures to facilitate and monitor the rehabilitation and return to work of employees who have suffered a stress-related illness is another aspect of tertiary prevention.

Tertiary prevention programs, usually in the form of an employee assistance program (EAP), traditionally have offered counseling for alcohol related and personal problems, but in the 1980s they became broader and expanded their programs to include stress-management programs. However, these EAP-based stress management programs typically do not seek to identify organization-centered problems, in part because EAP counselors lack training in organizational behavior and occupational stress. Rather, EAP-based programs offer counseling techniques used in community programs that emphasize personal or individual solutions to stress reduction (Quick, Murphy, Hurrell, \& Orman, 1992).

$$
\text { In practice, tertiary prevention }
$$
programs in the workplace are far more common than primary prevention programs, with secondary prevention programs intermediate in frequency (Reynolds, 1997; Cooper \& Cartwright, 2001; Cartwright \& Cooper, 1996). Organizations tend to prefer to introduce secondary and tertiary level interventions for several reasons: (i) There is relatively more published data available on the cost benefit analysis of such programs, particularly EAPs; (ii) Those traditionally responsible for initiating interventions, that is, the counselors, physicians, and clinicians responsible for health care, feel more comfortable with changing individuals than changing organizations;

(iii) It is considered easier and less disruptive to business to change the individual than to embark on any extensive and potentially expensive organizational development program, the outcome of which may be uncertain; (iv) They present a high profile means by which organizations can "be seen to be doing something about stress" and taking reasonable precautions to safeguard employee health (Cooper \& Cartwright, 2001).

\section{Towards an evidence - based approach of occupational stress management interventions}

A number of theories have been developed to conceptualize the problem of occupational stress and to explain and predict 
when work stress will occur. Depending on the emphasis of the theory, different implications for interventions result. Some of these theories concentrate on the stressors within the work environment (e.g., the demand-control/support model; Theorell \& Karasek, 1996), some focus on the mismatch between organizational requirements and rewards (e.g., the effortreward imbalance model; Siegrist, 1996), some have a greater focus on the resources available to employees to cope with demands (e.g., the conservation-of-resources model; Hobfoll, 1989; Hobfoll \& Spielberger, 1992; Best, Stapleton \& Downey, 2005; Hall, Royle, Brymer, Perrewe, Ferris, \& Hochwarter, 2006), and others focus on appraisal and coping to explain individual differences in reactions to stress at work (e.g., cognitive theory; Lazarus, DeLongis, Folkman \& Gruen, 1985; Folkman, Lazarus, Dunkel-Schetter, DeLongis, \& Gruen, 1986).

The above theories and conceptualizations provide a complex macroframework for delineating the phenomenon that is occupational stress. However, there is a considerable gap between postulating a descriptive theory and building a credible case for the allocation of resources to address stress in the workplace. As the type of action required by an organization will vary according to the kinds of stressors operating, any intervention needs to be guided by some prior diagnosis or stress audit or risk assessment to identify the organizational-, site-, or departmental-specific stressors responsible for employee stress (Capotescu, 2007).

As the push for evidence-based practice becomes stronger, there is a need for research to converge on evidence-based solutions to the strain experienced in the world of work. To establish a clear mandate for action, there is a need to identify not only the factors that affect occupational stress but also the effectiveness of specific interventions through empirical research (Caulfield, Chang, Dollard, and Elshaug, 2004). According to Briner (1997), by evidence-based we mean that the nature of causal relationships between the phenomena of interest are first established. The central premise of work on organizational stress is that there are causal links between work conditions and employee well-being. An evidence-based approach would in each case examine the nature and truth of such a premise by first conducting a thorough research.
Recent research has focused on stress management interventions. Nicholson, Duncan, Hawkis, Belcastro and Gold (1988) described and summarized the methods and results of 62 published reports on stress management programs from numerous fields. Programs crossed all levels of prevention, and most often took place in university, medical, or worksite settings. A meta-analysis of the quantitative results of a sample of these studies yielded mildly encouraging results. A meta-analysis conducted by Richardson and Rothstein (2008) to determine the effectiveness of stress management interventions in occupational settings suggested that intervention type played a moderating role. Cognitive- behavioral programs consistently produced larger effects than other types of interventions, but if additional treatment components were added the effect was reduced. Within a sample of 55 studies, relaxation interventions were most frequently used, and organizational interventions continued to be scarce. Effects were based mainly on psychological outcome variables, as opposed to physiological or organizational measures. The examination of additional moderators such as treatment length, outcome variable, and occupation did not reveal significant variations in effect size by intervention type.

Generally, evidence as to the success of stress management interventions is confusing and imprecise (Bunce \& Stephenson, 2000), which possibly reflects the idiosyncratic nature of the form and content of this kind of training.

Overall, evidence as to the success of interventions which focus at the individual level in isolation suggests that such interventions can make a difference in temporarily reducing experienced stress (Cooper \& Cartwright, 1997). Work-directed interventions showed the most consistent effects on job stress (Taris, Kompier, Geurts, Schreurs, Schaufeli, de Boer, Sepmeijer, \& Watterz , 2003).

Some recent studies that have evaluated the outcome of stress management interventions have found a modest improvement in self-reported symptoms and psychological indices of strain, but little or no change in job satisfaction and motivation (Bond \& Bunce, 2000). Saunders, Driskell, Johnston, \& Salas (1996) conducted a metaanalysis to determine the overall effectiveness of stress inoculation training in workplace settings and to identify conditions that may 
moderate the effectiveness of this approach. The analysis was based on a total of 37 studies with 70 separate hypothesis tests, representing the behavior of 1,837 participants. Results indicated that stress inoculation training was an effective means for reducing performance anxiety, reducing state anxiety, and enhancing performance under stress. Furthermore, the examination of moderators such as the experience of the trainer, the type of setting in which training was implemented, and the type of trainee population revealed no significant limitations on the application of stress inoculation training to applied training environments.

Evidence as to the success of interventions which focus at the individual level in isolation suggests that such interventions can make a difference in temporarily reducing experienced stress. In a study conducted by Reynolds (1997), an individual-level intervention was compared with an organizational-level intervention aimed at increasing employees' participation and control. The individually oriented intervention proved clearly superior.

Caulfield, Chang, Dollard and Elshaug (2004) investigated empirical research into occupational stress interventions conducted in Australia within the past 10 years. Most interventions were individually focused, despite the preponderance of research identifying risky work environment stressors. Results suggest a paucity of published information regarding what works with occupational stress interventions in Australia and an urgent need for further research in the area, particularly focusing on the private sector, rural workers, and scientific evaluation.

While it is important to develop workplace practices that promote positive health outcomes and remediate negative stress and health outcomes, it is also important that organizations focus on the needs of employees in developing such programs (Munz \& Kohler, 1997). Employees in organizations do not all have the same values, expectations of work, backgrounds, and family arrangements. If programs do not align with the needs of employees, then it would be expected that employees would not use them, thus reducing the positive benefits of such programs (Grawitch, Gottschalk, \& Munz, 2006). Therefore, it is important to assess not only actual practices, but also the extent to which employees value and are satisfied with those practices.
An evidence-based approach would also include treating the stress claims made by organizations with caution. Stress is often treated as though it is a purely scientific phenomenon, somehow immune from cultural and social influence. The reason employees make complaints about stress may often be highly symbolic (ex. in response to feeling undervalued or politically powerless).

\section{Concluding remarks and future directions}

Generally, evidence as to the success of stress management interventions is confusing and imprecise, which possibly reflects the idiosyncratic nature of the form and content of this kind of interventions. The level of research activity in the area of occupational stress and stress prevention varies considerably from country to country, as does the level of organizational activity.

Organizational intervention studies have reported several problems in acquiring controlled evidence on the effects of the actions. Flexibility of modern organizations rapidly destroys experimental conditions and weakens or complicates the interpretation of results. In addition, when planning a fieldexperimental study design, external and internal validity pull in different directions. A single study design does not offer optimal grounds for drawing both theoretical and practical conclusions (Elo et al., 2008). Much more research is needed, particularly studies that evaluate the long-term effectiveness of stress intervention strategies. There is also much to be learned from the dissemination of more practical case studies of organizational practice and experience in stress prevention. Stronger industrial links between the business community and academic institutions can promote this type of activity, particularly when there is some joint investment.

There are clearly a number of issues in this field that need urgent resolution. First, there are major logistic difficulties that arise in attempting to assess organizational-level stress interventions. Research with adequate methodology involving scientific evaluations is extremely rare in this field. Moreover, programs introduced by organizations vary widely in terms of their objectives, structure, and target groups. Internal and external threats to validity are often difficult to manage and may obscure the real effects of these programs. Alternatively, the paradigms underpinning 
current stress intervention programs may be fundamentally flawed.

As Martin (1992) suggested, although stress is a complex phenomenon, any discussion of it is necessarily framed in a specific, usually limited context. In designing occupationally appropriate stress training, we need a range of perspectives varying from the individual/subjective to a societal/objective point of view. Indeed, the physical reality of the individual stress response, with its cascading physiological, psychological, and behavioral effects as mediated by the presence and role of others, underlines the objective reality of our mental and physical interdependence on each other. Thus, dealing with stress inevitably requires dealing with self, others, and an external world beyond relationships. Given this view of stress, the pivotal issue for stress training is the way a person learns, especially from her or his own experience, and applies these learnings to competently deal with her or his situation. This puts the focus of stress training on experiential learning, the primary means by which almost all of us learn about our selves and develop our skills for managing self and situation.

The high cost of work stress related problems highlights the need to spend more time evaluating work stress interventions and publishing the findings so that other organizations can gain insight into programs of merit. As Kompier et al. (2000) suggested, there exists at present a large gap between theory and practice. Without further research, our knowledge of what works with regard to occupational stress will remain stunted. Questions surrounding the issue of whether stress prevention actually works; which interventions are most effective, and why; and the costs and limitations of various interventions need to be explored further. Future work in this area should focus on intervention studies or programs that have not been published and delving into the gray area of work stress interventions to find out what industry is actually doing to tackle the work stress situation.

\section{References}

Aryee, S., Luk, V., Leung, A., \& Lo, S. (1999). Role Stressors, Interrole Conflict, and Well-Being: The Moderating Influence of Spousal Support and Coping Behaviors among Employed Parents in Hong Kong. Journal of Vocational Behavior,54, 259-278.
Atella, M.D. (1999). Case Studies in the Development of Organizational Hardiness. From Theory to Practice. Consulting Psychology Journal: Practice and Research, 51, 2, 125-134.

Best, R.G., Stapleton, L.M., \& Downey, R.G. (2005). Core Self-Evaluations and Job Burnout: The Test of Alternative Models. Journal of Occupational Health Psychology,10, 4, 441451.

Bond, F.W., \& Bunce, D. (2000). Mediators of change in emotion-focused and problemfocused worksite stress management interventions. Journal of Occupational Health Psychology, 5,1, 156-163.

Briner, R.B. (1997). Improving Stress Assessment: Toward an Evidence-Based Approach to Organizational Stress Interventions. Journal of Psychosomatic Research, 43, 1, 61-71.

Bruck, C.S., \& Allen, T.D. (2003). The relationship between big five personality traits, negative affectivity, type $A$ behavior, and work-family conflict. Journal of Vocational Behavior, 63, 457-472.

Bunce, D., \& Stephenson, K. (2000). Statistical Considerations in the Interpretation of Research on Occupational Stress Management Interventions. Work \& Stress, 14, 3, 197-212.

Capotescu, R. (2006). Stresul ocupațional. Teorii, modele, aplicații. Iaşi: Editura Lumen.

Capotescu, R. (2007). Aspecte metodologice în investigarea stresului ocupațional. Tehnici şi metode de diagnoză. În M. Milcu, C. Răulea, R. Sassu (Eds.) Cercetarea psihologică modernă: Direcții şi Perspective, Sibiu: Psihomedia, p 113-121.

Cartwright, S., \& Cooper, C.L. (1996). Public Policy and Occupational Health Psychology in Europe. Journal of Occupational Health Psychology, 1, 4, 349-361.

Cassidy, C., \& O'Connor, R.C. (2004). Perceived Discrimination and Psychological Distress: The Role of Personal and Ethnic SelfEsteem. Journal of Counseling Psychology Copyright 2004 by the American Psychological Association 51, 3, 329-339.

Caulfield, N., Chang, D., Dollard, M.F., \& Elshaug, C. (2004). A Review of Occupational Stress Interventions in Australia. International Journal of Stress Management,11, 2, 149166.

Contrada, R.J. (1989). Type A Behavior, Personality Hardiness, and Cardiovascular Responses to Stress. Journal of Personality and Social Psychology,57, 5, 895-903. 
Cooper, C.L., \& Cartwright, S. (1997). An Intervention Strategy for Workplace Stress. Journal of Psychosomatic Research, 43, 1, 716.

Cooper, C.L., \& Cartwright, S. (2001). Organizational Management of Stress and Destructive Emotions at Work. In R.L. Payne, C.L. Cooper, (Eds.), Emotions at Work. Theory, Research and Applications for Management, Chichester, England, John Wiley and Sons, p. 269-280.

Daniels, K., \& Guppy, A. (1997). Stressors, Locus of Control and Social Support As Consequences of Affective Psychological Well Being. Journal of Occupational Health Psychology,2, 2, 156-174.

Eddleston, K.A., Veiga, J.F., \& Powell, G.N. (2006). Explaining Sex Differences in Managerial Career Satisfier Preferences: The Role of Gender Self-Schema. Journal of Applied Psychology,91, 2, 437-445.

Elo, A., Ervasti, J., Kuosma, E., \& Mattila, P. (2008). Evaluation of an organizational stress management program in a municipal public works organization. Journal of Occupational Health Psychology, 13,1, 10-23.

Folkman, S., Lazarus, R.S., Dunkel-Schetter, C., DeLongis, A., \& Gruen, R.J. (1986). Dynamics of a Stressful Encounter: Cognitive Appraisal, Coping and Encounter Outcomes. Journal of Personality and Social Psychology, 50, 5, 992-1003.

Grawitch, M.J., Trares, S., \& Kohler, J.M. (2007). Healthy workplace practices and employee outcomes. International Journal of Stress Management, 14, 3, 275-293.

Gross, J.J., Carstensen, L.L., Tsai, J., Skorpen, C.G., \& Hsu, A.Y. (1997). Emotion and Aging: Experience, Expression, and Control. Psychology and Aging, 12, 4, 590-599.

Hall, A.T., Royle, M.T., Brymer, R.A., Perrewe, P.I., Ferris, G.R., \& Hochwarter, W.A.(2006). Relationships Between Felt Accountability as a Stressor and Strain Reactions: The Neutralizing Role of Autonomy Across Two Studies. Journal of Occupational Health Psychology, 11,1, 87-99.

Hobfoll, S.E. (1989). Conservation of Resources. A New Attempt at Conceptualizing Stress. American Psychologist, 44, 3, 513-524.

Hobfoll, S.E., \& Spielberger, C.D. (1992). Family stress: Integrating Theory and Measurement. Journal of Family Psychology, 6, 2, 99-112.

Hochwarter, W.A.,Witt, L.A., Treadway, D.C., \& Ferris, G.R. (2006). The Interaction of Social Skill and Organizational Support on Job
Performance. Journal of Applied Psychology, 92, 2, 482-489.

Hudek-Knezevic, J., \& Kardum, I. (2000). The effects of Dispozitional and Situațional Coping, Perceived Social Support, and Cognitive Appraisal on Immediate Outcome. European Journal of Psychological Assessment, 16, 3, 190-201.

Ivancevich, J.M., Matteson, M.T., Freedman, S.M., \& Philips, J.S. (1990). Worksite Stress Management Interventions. American Psychologist, 45, 2, 252-261.

Jex, S. M., Beehr, T. A., \& Roberts, C. K. (1992). The meaning of Occupational Stress Items to Survey Respondents. Journal of Applied Psychology, 77, 5, 623-628.

Kenny, D.T., \& Cooper, C.L. (2003). Introduction: Occupational Stress and Its Management. International Journal of Stress Management, 10, 4, 275-279.

Krajewski, H.T., \& Goffin, R.D. (2006). Predicting Occupational Coping Responses: The Interactive Effect of Gender and Work Stressor Context. Journal of Occupational Health Psychology, 10, 1, 44-53.

Lazarus, R.S., DeLongis, A., Folkman, S., \& Gruen, R. (1985). Stress and Adaptational Outcomes. The Problem of Confounded Measures. American Psychologist, 40, 7, 770-779.

Le Blanc, P., de Jonge, J., \& Schaufeli, J. (2000). Job Stress and Health. În Chmiel, N. (Ed.) Work and Organizational psychology. A European Perspective. Oxford: Blacwell Publishers Ltd.

Long, B.C., Kahn, S.E., \& Schultz, R.W. (1992). Causal Model of Stress and Coping: Women in Management. Journal of Counseling Psychology, 39, 2, 227-239.

Long, B.C., \& Schultz, R.W. (1995). Temporal Stability and Replicability of a Workplace Stress and Coping Model for Managerial Women: A Multiwave Panel Study. Journal of Counseling Psychology, 42, 3, 266-278.

Martin, E.V. (1992). Designing stress training. In Quick, J. Campbell; R.L. Murphy; J.J.Jr. Hurrell, (Eds.). Stress \& well-being at work: Assessments and interventions for occupational mental health. (pp. 207-224). Washington, DC, US: American Psychological Association.

Nicholson, T., Duncan, D.F., Hawkis, W., Belcastro, P.A., \& Gold, R. (1988). Stress Treatment: Two Aspirins, Fluids, and One More Workshop. Professional Psychology: Research and Practice, 19, 6, 637-641. 
Peake, A., \& Harris, K.L. (2002). Young Adults' Attitudes toward Multiple Role Plsanning: The Influence of Gender, Career Traditionality, and Marriage Plans. Journal of Vocational Behavior, 60, 405-421.

Portello, J.Y., \& Long, B.C. (2001). Appraisal and Coping with workplace International Stress: $A$ model of Women Managers. Journal of Counseling Psychology,48, 2, 144-156.

Quick, J.C., Murphy, L.R., Hurrell, J.J., \& Orman, D. (1992). The value of work, the risk of distress, and the power of prevention. In Quick, J. Campbell; R.E. Murphy; J.J.Jr., Hurrell (Eds.). Stress \& well-being at work: Assessments and interventions for occupational mental health. (pp. 3-13). Washington, DC, US: American Psychological Association

Quick, J.C., Quick, J.D.,Nelson, D.L., Hurrell, J.J. (1997) Preventive stress management: From threat to opportunity. In Quick, J. Campbell; J. D; Quick; D. L. Nelson, J.J.Jr., Hurrell (Eds.) Preventive stress management in organizations. (pp. 301-307). Washington, DC, US: American Psychological Association, 368 pp.

Reynolds, S. (1997). Psychological Well-Being at Work. Is Prevention Better than Cure? Journal of Psychosomatic Research, 43, 1, 93-102.

Richardson, K.M., \& Rothstein, H.R. (2008). Effects of occupational stress management intervention programs: A meta-analysis. Journal of Occupational Health Psychology, 13,1, 69-93.

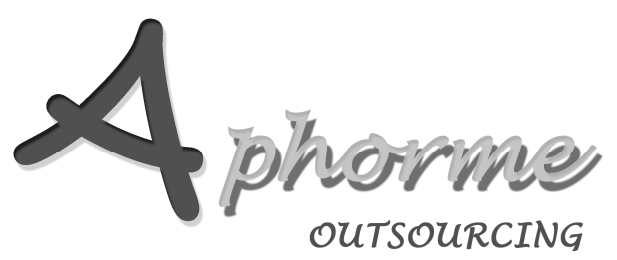

Saunders, T., Driskell, J.E.,Johnston, J.H., Salas, $E$. (1996). The effect of stress inoculation training on anxiety and performance. Journal of Occupational Health Psychology, 1, 2, 170-186.

Schonfeld, I., Jaesoon, R., Xia, F. (1995). Methodological Issues in Occupational-Stres Research: Research in One Occupational Group and Wider Applications. În S. Sauter, L. Murphy, (Eds.), Organizational Risk Factors for Job Stress. Washington, DC: American Psychological Association.

Shaffer, M.A., Bell, M.P., Joplin, J.R., Theresa Lau, T., Oguz, C. (2000). Disruptions to Women's Social Identity: A Comparative Study of Workplace Stress Experienced by Women in Three Geographic Regions. Journal of Occupational Health Psychology, 5, 4, 441456.

Siegrist, J. (1996). Adverse Health Effects of HighEffort/Low-Reward Conditions. Journal of Occupational Health Psychology, 1, 1, 27-41.

Taris, T.W., Kompier, M.A.., Geurts, S.A., Schreurs, P.J., Schaufeli, W.B., de Boer, E., Sepmeijer, K.J., Watterz, C. (2003). Stress Management Interventions in the Dutch Domiciliary Care Sector: Findings From 81 Organizations. International Journal of Stress Management, 10, 4, 297-325.

Theorell, T., Karasek, R.A. (1996). Current Issues Relating to Psychosicial Job Strain and Cardiovascular Disease Research. Journal of Occupational Health Psychology,1, 1, 9-26.
Organizational Diagnosis \& Development Brand Research Academic \& Institutional Evaluation Organizational Simulation \& Gaming

Focus on people and opportunities.

For reliable outcomes contact@aphorme.ro; www.aphorme.ro 